J.F. Merritt

14 Illingworth Way

Foxton CB22 6RY

\title{
'Voluntary Bounty and devotion to the Service of God'? Lay patronage, protest and the creation of the parish of St Paul Covent Garden 1629-41
}

The earl of Bedford's Covent Garden development in the 1630s is famous for its bold, classical design and its emphasis on uniform housing, aimed at creating an exclusive gentry enclave. It has been seen by recent historians as providing a model of Charles I's ideals of order and symmetry that would both mirror and facilitate an orderly society. ${ }^{1}$ The importance of the development in the political and cultural history of the period is clear. However, another significant aspect of the Covent Garden development has largely escaped the attention of historians. For Covent Garden was not merely an architectural scheme or commercial development; it also resulted in the creation of a new parish in the heart of the emerging West End, a short distance from Whitehall Palace. The building of an entirely new church accompanied by the

${ }^{1}$ D. Duggan, “ "London the ring, Covent Garden the jewell of that ring”: new light on Covent Garden', Architectural history xliii (2000); R.M. Smuts, $\underline{\text { Court culture and the }}$ origins of a royalist tradition in early Stuart England (Philadelphia, 1987), pp. 128, 139, 166; K. Sharpe, The Personal Rule of Charles I (New Haven, 1992), p. 412; R.M. Smuts, 'The court and its neighbourhood: royal policy and urban growth in the early Stuart West End', Journal of British Studies xxx (1991), 117-49 at pp. 120, 14043, 149. I am grateful to the British Academy for their financial assistance in researching this article. 
creation of a new parish had hitherto been a very rare - almost unparalleled -phenomenon in post-Reformation England..$^{2}$ It raised a whole series of questions and problems, including who should pay for the new church and its furnishings, who should appoint the minister and pay his wages, and how the new parish should be governed. Studies of parochial communities in early modern England are usually concerned with mapping changes and developments within existing local hierarchies and established loyalties. But how easily could such hierarchies and loyalties be established ex nihilo within the new parish?

Covent Garden's extraordinary prominence in the early modern capital gives these questions particular importance, but they have not been considered by earlier historians of this famous development. And this despite the fact that the proposed creation of a new parish in Covent Garden would seem to have been the trigger for an unparalleled flood of parliamentary bills for creating new parishes. ${ }^{3}$ Partly this

\footnotetext{
${ }^{2}$ There are examples of very substantial rebuilding of existing churches in this period, but very few of churches built from scratch: see J.F. Merritt, 'Puritans, Laudians and

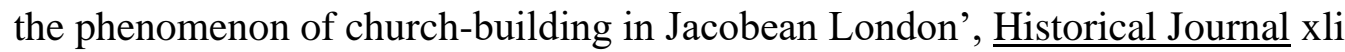
(1998), 935-60; K. Fincham and N. Tyacke, Altars restored. The changing face of English religious worship, 1547-c.1700 (Oxford, 2007), pp. 100-01.

${ }^{3}$ Bills for the subdivision of the western parishes of St Andrew Holborn and St Giles Cripplegate followed hard on the heels of those for the creation of the parish of St Paul Covent Garden: see Commons' Journals, II, 80, 96, 162, 277 (and for other metropolitan examples see ibid., II, 277 and below, n. 25). The fact that it was known in advance of the meeting of the Long Parliament that Covent Garden would be granted parochial status may also explain the unparalleled run of other bills for the creation of new parishes elsewhere in the country in early to mid-1641 (Lords' 
historical lacuna reflects problems of evidence: Covent Garden has no churchwardens' accounts or vestry minutes for this period, crucial parts of the bishop of London's episcopal register are missing, and the patchy surviving materials offer only tantalizing glimpses of what was going on. Yet careful contextualization and linkage of disparate evidence can actually provide us with a remarkably rich picture of the birthpangs of this prominent new parish. People involved included some of the most prominent figures in England, from Bedford, Lord Treasurer Juxon and Archbishop Laud through to the King himself. The manner in which problems of authority and identity in the new parish were argued over also helps to shed new light on many of the more controversial features of the 1630s, from conflicts over the boundaries between lay and clerical authority to concerns over popular petitioning. As we will see, behind the order and symmetry of Covent Garden's classical architecture lay the messy reality of factional conflict, power struggles, popular petitions, and resentful stalemate.

We should begin with the developer of Covent Garden, the fourth Earl of Bedford, and the scope and nature of his ambitions for the development. Recent historiography

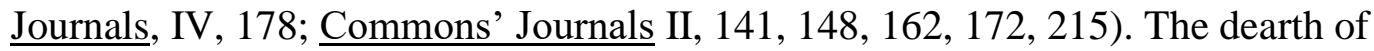
previous cases in Commons' Journals or Lords' Journals would certainly suggest this. A later ordinance of September 1654 empowered trustees to recommend unions or divisions of parishes: C. Firth and R. Rait (eds.), Acts and Ordinances of the Interregnum 1642-1660 (3 vols., 1911), II, pp. 1000-06. 
has demonstrated that many of the most distinctive architectural aspects of Covent Garden were actually dictated by Charles I and Inigo Jones, who made significant changes to the plot of the buildings and enforced on Bedford strict regulations on building materials and architectural uniformity. ${ }^{4}$ It is nevertheless important to resist the temptation to see Bedford as a passive figure who had been manipulated into paying for the larger architectural vision of Inigo Jones and the king. Instead, it is instructive to consider the development of Covent Garden not merely from the perspective of Whitehall, but quite literally from that of Bedford House. Bedford seems to have always intended that the development should constitute an independent parish, and was emphatic that his own older residence of Bedford House should form part of this new parish, despite the fact that this would involve awkwardly extending the new parish boundary down to the Strand.

The earl's desire to include Bedford House as part of his new development also explains one of the oddities of Covent Garden's famous piazza: that its southern side had no houses. ${ }^{5}$ To nineteenth-century critics this was an obvious architectural flaw, but this anomaly becomes far more comprehensible when we factor in Bedford House and its gardens, which formed a distant fourth side to the development. The lack of houses therefore provided an uninterrupted vista of Covent Garden piazza from a raised walkway within the grounds of Bedford House. Moreover, recent research would seem to indicate that, contemporaneous with the development of the piazza, additions were made to the new north range of the Bedford House complex

\footnotetext{
${ }^{4}$ Smuts, Court culture, p. 128; Smuts, 'The court', p. 120; Duggan, 'London the ring', pp. 143-9.

${ }^{5}$ Survey [of London: volume 36: Covent Garden (1970)], pp. 77-80.
} 
that faced the new development, and a large Italianate garden laid out. As a result, Bedford House itself could thus be seen as forming a planned element of the piazza. ${ }^{6}$

If Covent Garden was visually and conceptually in the earl of Bedford's 'backyard', this was also emblematic of how Bedford saw the prospective parish of Covent Garden and social relations within it. While Bedford undoubtedly had strong commercial motives for the development (and indeed cut costs and ensured that most of the actual building was done by leasees), there is a danger in simply portraying him as a commercial developer. It was being reported in 1632 that Bedford was erecting at Covent Garden 'a newe town or edifices in the nature therof' and in many ways this was true. ${ }^{7}$ This was to be virtually a new 'town' at the heart of Westminster that would fall directly under Bedford's control as its principal resident. Even before the building began Bedford was proposing that he be allowed the "power to keepe a Markett everie weeke' in Covent Garden 'on such daie as the said Earle shall thinke most fit for the said Inhabitants'. ${ }^{8}$ As we will see, he also intended to control the appointment and payment of the minister of the new parish, and his clients and supporters moved swiftly to try to take control of local affairs. The ordinance that finally established the new parish not only granted the earl the patronage of the living in perpetuity, but more unusually even exempted Bedford House from a range of parish rates. ${ }^{9}$ While Malcolm Smuts entitled his study of the leasees of Covent Garden 'the court and its neighbourhood', it is arguably just as important to study the

${ }^{6}$ D. Duggan, 'The fourth side of Covent Garden Piazza: new light on the history and significance of Bedford House', British Art Journal 3/3 (2001-2), 53-65.

${ }^{7}$ Duggan, 'London the ring', p. 145.

${ }^{8}$ Alnwick Castle, Y.III.2/4, envelope 8.

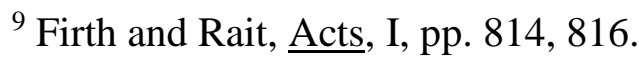


perspective of 'Bedford House and its neighbourhood' in order to understand the social dynamics of the new parish. Bedford's vision, then, rested on his assumption of his dominance in the area - yet this was no rural backwater, but the more complex environment of the early modern metropolis. It was his determination to make a social and political reality of this dominance that would trigger a great deal of the unrest that followed.

Historians' attention has tended to focus on the problems that Bedford had met in gaining his license from the crown to build in Covent Garden in the first place (given the restrictions on building in early modern London) and his further setbacks when the conditions of the original license were subsequently questioned in Star Chamber. This resulted in 1635 in a substantial fine of $£ 2000$ for Bedford's supposed breach of the capital's building regulations. ${ }^{10}$ It is often implied that all went smoothly in Covent Garden after these proceedings, but this is to ignore a whole series of subsequent conflicts that were bound up with the earl of Bedford's building of a new church as part of the development. It is the ramifications of this decision, and the attempt to extend this into the creation of a new parish, which will be explored here.

Originally the Covent Garden development was located within (and would ultimately be carved out of) the fashionable West End parish of St Martin in the Fields. The decision to include a church in the Covent Garden development was initially linked directly with St Martin's increasing need for a chapel of ease. The population of St Martin's parish had trebled during the Jacobean period, and although the church of St Martin's had been enlarged around 1607, parish officials had for some years been

\footnotetext{
${ }^{10}$ On the Star Chamber case see especially D. Duggan, 'The prosecution of the earl of Bedford', London topographical record xxix (2006), 1-21.
} 
urgently seeking an additional chapel. They made a sustained but unsuccessful attempt to be permitted to convert a vacant 'Church like' hall in Durham House on the Strand into a chapel, ${ }^{11}$ but with the failure of this initiative the parish turned its gaze to Covent Garden. As early as 1619 the parish had considered obtaining ground in the area for a chapel, so Bedford's planned Covent Garden development provided an ideal opportunity to revive the idea of having a church there. ${ }^{12}$ A royal warrant dated May 1629 for drawing up a license for Bedford to build in Covent Garden notes the fact that the parish church of St Martin's 'is not capable to receive all the inhabitants by two thousand communicants and more'. After the recent failure of their suit for part of Durham House, it continues, the incumbent Thomas Montford and the bishop of London (William Laud) 'with many of the inhabitants' had asked the earl of Bedford for 'so much grounde parcell of his feilde called Covent garden scituat within the said parish as might serve for the building of a small church or a Chappell of ease'. According to the warrant, Bedford had then decided to satisfy their desires by undertaking to dedicate for that use 'a spacious and large' proportion of the ground and would contribute $£ 3000$ 'towards the building and adorning of the said church and churchyard'. It is implied, at least, that it was Bedford's provision of a new

\footnotetext{
${ }^{11}$ J. F. Merritt, The social world of early modern Westminster (Manchester, 2005), pp. 321-2; W[estminster] A[rchives] C[entre] F2001, fol. 133; F3, fol. 102; T[he]

$\mathrm{N}$ [ational] A[rchives], P[ublic] R[ecord] O[ffice], SP16/44/51.

${ }^{12}$ Merritt, Social world, p. 322.
} 
church that had been the concession required to obtain his license from the king to build new houses. ${ }^{13}$

But things were not to be quite so straightforward. In particular, a new church raised issues of lay and clerical authority: how far could this new development be taken to constitute a new parish? And who should appoint and pay the minister? ${ }^{14}$ These problems were flagged by Attorney General Noy in a paper of directions that he seems to have drawn up in late 1631/early 1632. Noy allowed that the new chapel might have a perpetual incumbent and 'all parochial rights', but only with the consent of the dean and chapter of Westminster and the vicar of St Martin's (a significant qualification). Noy noted that it was fitting that the right of presentation be appointed to some certain person (without specifying that this should be the founder). $\mathrm{He}$ particularly urged that the incumbent should be properly paid 'and not to be left to the willing contribution of his flock'. ${ }^{15}$ But these matters were not entirely resolved. While the letters patent dated 30 June 1635 that confirm Bedford's building license note that Bedford has 'erected a Building for a Church there verey competent for a

${ }^{13}$ Alnwick Castle, Y.III/2/1, envelope 2; Duggan, 'London the ring', p. 143. A draft of the license has the earl contributing only $£ 2000$ towards the cost of the church; presumably it was conveyed that this would be inadequate (Y.III/2/4, envelope 8). 14 St Martin's parishioners in 1626 had proposed that they would pay the minister of 'this new church' (at Durham House) while still paying their dues to 'the present and future vicars of the old Church'. They presumably hoped that, as attendance at this new church on the Strand would be more convenient for 'the most parte of the parishioners Especially of noble personages and other of the better sort', the money would be easily forthcoming (TNA, SP 16/44/51).

${ }^{15}$ Alnwick Castle, Y.III.2/4, envelope 10; Duggan, 'London the ring', p. 144. 
parochiall Church' they make no direct comment on the questions that Noy had raised. ${ }^{16}$ One man who was clearly unhappy with developments and these still unresolved questions would appear to have been Archbishop Laud.

Laud had reason to be highly suspicious of the new church and parish. St Martin's had been involved in a tense stand-off with the king over the appointment of its lecturer in 1627. In the following years another parish lecturer's inflammatory sermons at St Martin's had led to his brief suspension by Laud (acting as bishop of London) and the cross-examination of St Martin's churchwardens. To make matters worse, a further temporary replacement lecturer was in his turn summoned before Laud in 1631 for his sermon that had attacked bowing at the name of Jesus (a particularly controversial issue that was generating heated pamphlet exchanges between puritans and Laudians at precisely that time). ${ }^{17}$ In this context, the Covent Garden development must have seemed sinister to Laud. The fourth earl of Bedford was not himself a zealous puritan, but he certainly associated with some more militantly godly figures, acted as patron to Cornelius Burges (who was already in trouble with the authorities in the 1630s and would be a scourge of Laudianism in the

\footnotetext{
${ }^{16}$ TNA, C66/2692, no.1. This is particularly notable as a draft of the license among Bedford's papers contains an interpolated section (missing in the final version) which specifies that the church is 'fit to be ... consecrated, and to be made presentative and the said Earle his heirs and assigns to be patrons thereof, and the encumbentes therof to have all parochiall rights within the precinct': Alnwick Castle, Y.III.2.9. ${ }^{17}$ Merritt, Social world, pp. 345-6; Fincham and Tyacke, Altars restored, pp. 139-40.
} 
early 1640s) and favoured leniency towards nonconforming ministers. ${ }^{18}$ Not only was the puritan-connected Bedford apparently determined to control the appointment of the minister to the new church (the 1629 warrant had already implied that Bedford would control the living), but the patronage of the new church had also arisen during the 1633 trial of the puritan consortium, the Feoffees for Impropriations. It was reported that the feoffees had consciously targeted the new church of Covent Garden in their attempts to place puritan ministers in influential parishes, and that they had offered Bedford $£ 1000$ to buy the advowson. In their defence, the feoffees retorted that 'a Lord' had sent his solicitor to them, and that it was he who had proposed the deal. ${ }^{19}$ Perhaps even more troubling than Bedford's alleged activities was the fact that the new minister whom the feoffees appear to have envisaged for the Covent Garden position was the notorious Thomas Foxley. Foxley was none other than the preacher whom Laud had so recently suspended for his sermons at St Martin's (as well as serving as the morning lecturer at the puritan St Antholin's). Moreover, Foxley emerged from the trial as a prominent associate of the feoffees (indeed, he was one of the defendants, and had clearly taken charge of anonymous donations to the feoffees) ${ }^{20}$ Laud certainly continued to view the new Covent Garden pulpit as a potentially dangerously platform for puritan preaching: when a strong sabbatarian was

${ }^{18}$ On Bedford's religion compare Duggan, 'London the ring', pp. 149-53 with Conrad Russell's analysis of Bedford's religious 'eclecticism' in Oxford DNB. See also J. Adamson, The noble revolt (2007), pp. 30n, 141-4, 424.

${ }^{19}$ I.M. Calder, Activities of the puritan faction of the Church of England, 1625-1633 (1957), pp. 54, 79-80, 89, 100.

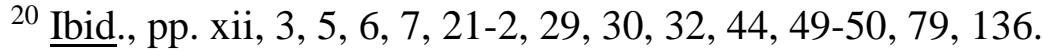


appointed to a lectureship there in 1640 Laud commented sourly that 'it will be the famousest place in England', ${ }^{21}$

While Laud may have been concerned with securing control of the living and the appointment of the minister, it was actually William Bray, the new vicar of $\mathrm{St}$ Martin's, who acted in this matter, protesting that he alone had the right to appoint the minister of the new chapel of Covent Garden, and not Bedford. But the sources (and historians who have briefly mentioned the incident) do not mention the rather obvious point that Bray was Laud's chaplain. Indeed, after earlier clashes with the parish Laud had moved swiftly to insert Bray as the new vicar of St Martin's after the death of the incumbent in March 1633, and soon after he had placed another of his chaplains (William Haywood) in the adjacent parish of St Giles in the Fields. Here perhaps was a broader scheme to gain control of the politically-influential western parishes of the metropolis, which would have been immediately threatened by the risk of losing control of a new parish and advowson.

That Bray was acting as Laud's agent in this matter seems highly likely. Certainly, the new vicar of St Martin's was rarely to be found in his own parish. Bray usually remained with his patron: St Martin's churchwardens often had to attend on him at Lambeth or at Croydon when they needed to discuss parish business with him, and the parish's new church plate was taken over to Lambeth for consecration by Laud himself (despite the fact that by this time it was Bishop Juxon who had jurisdiction over St Martin's as bishop of London). Bray also continued as Laud's chaplain, in which post he licensed the notorious Laudian publications of John Pocklington. ${ }^{22}$ It is inconceivable that Bray, in challenging the rights of an influential

${ }^{21}$ Calendar of state papers domestic 1640-41, p. 212.

${ }^{22}$ Merritt, $\underline{\text { Social world, pp. 346-8. }}$ 
nobleman who apparently had the king's warrant for his development, was acting on his own. He must surely have been proceeding at least with Laud's approval, and presumably under Laud's instructions.

Covent Garden therefore would appear to represent a prominent confrontation between Laud and lay authority in religious matters that has been missed by previous historians. Laud's concern over the new church of Covent Garden may have reflected more than his concerns with the locality - there was also a principle at stake concerning lay intrusion into the powers of the church. Bedford, after all, was seeking permanent control over a new church to which he was contributing. And yet elsewhere, there were other recent examples of new churches being established where arrangements had doubtless been more to Laud's taste. One obvious case was that of Abbey Dore, restored by Laud's protégé Viscount Scudamore, who had claimed no special rights and had endowed the church with 'the manor house and lands, the impropriate rectory and all the tithes from the hitherto exempt site and demesne of the abbey'. ${ }^{23}$ Laud had himself recently been involved as bishop of London with the new building in 1630 of the parish church of Great Stanmore in Middlesex, which the merchant and financier Sir John Wolstenholme had paid for with no strings attached. ${ }^{24}$ Even closer to home was the example of the Broadway chapel in the St Martin's sister parish of St Margaret's, erected with the help of a bequest of some

\section{${ }^{23}$ I. Atherton, Ambition and failure in Stuart England. The career of John, first}

Viscount Scudamore (Manchester, 1999), pp. 59-63.

${ }^{24}$ G[uildhall] L[ibrary], MS 9531/15, fols. 3v-4r; Victoria County History of

Middlesex V (1976), pp. 105-7. The church contained an octagonal font bearing Wolstenholme's arms, by Nicholas Stone. Wolstenholme was the co-dedicatee of the extreme Laudian tract De Templis (1638). 
$£ 400$ from Laud's fellow Westminster prebendary, George Darrell, who died in 1631. Darrell's bequest specified that the chapel was intended 'for the inhabitants of those parts of the Towne now utterly unprovided in the necessary grounds of religion', and there was no suggestion that it would form the basis of a new parish, although St Margaret's population was even greater than that of St Martin's. ${ }^{25}$ Here were outright charitable donations with no hidden clauses, with no attempt to claw back money from parishioners or to make a claim to tithes, or to effect jurisdictional change with the creation of a new parish. Montford (the old vicar of St Martin's) and Laud may well have been aware of the intentions of their fellow-prebendary Darrell when they made their approach to Bedford in 1629 about a new chapel of ease for St Martin's, and they presumably expected a similar arrangement. However, in the event, Bedford's development was clearly a very different matter indeed.

Despite Bray and Bedford tussling over the right to appoint the minister, building work continued and the church of St Paul's was completed in 1633. But this was not before the ill-fated church had encountered problems regarding its orientation, with the chancel initially sited towards the geographical west, with the main entrance unconventionally located at the east end. The subsequent requirement that the interior of the church be re-orientated would seem to represent the direct intervention of Laud as bishop of London (and would have come hard on the heels of his insistence that a new chapel built in Hammersmith should 'be built as other

${ }^{25}$ P. Guillery, 'The Broadway Chapel, Westminster: a forgotten examplar', London topographical record xxvi (1990), 97-133 at pp. 106-8. Proposals in 1642 that it form a new parish seem to have followed on the back of petitions for Covent Garden: V.F. Snow and A.S. Young (eds.), The private journals of the Long Parliament 7 March to 1 June 1642 (New Haven, 1987), p. 141. 
churches are, east and west, without tricks'). ${ }^{26}$ This also provides further testimony of his intense scrutiny of the new church (and also, perhaps, of an awareness that it might serve as a model for others). Even after the costly re-orientation of the church, however, it was not consecrated, as the stand-off between Bray and Bedford remained unresolved. The result was that this striking new church, at the heart of Westminster's new fashionable development, remained for five long years without 'any settled Course' for the supply of a preaching minister, and apparently (because of its unconsecrated state) unable to house divine service. ${ }^{27}$

It is notable that a remarkably similar stand-off and suspended consecration had occurred in precisely the same year as the completion of Covent Garden church. The case of St John's Leeds also involved the building of a new church within an

${ }^{26}$ William Laud, Works ed. J. Bliss and W. Scott (7 vols., Oxford, 1847-60), VII, p. 25. William Prynne claimed that the Covent Garden church was commanded to be switched around 'to the great expence of the builder, the hindrance, and deformity of that good worke'. It seems clear that King Charles and Inigo Jones had viewed plans showing that the church was aligned on this axis and had made no complaint, and the alteration was presumably required by Laud as bishop of London, as the building accounts suggest that alterations were being made well before he succeeded Abbot as archbishop in 1633 (Survey, p. 100). A draft of the 24 May 1639 privy council order (for which see below) alludes to the "charges for alteration which the Bishop of the diocesse and Chancellor of the same appointed before the Consecration to bee done': TNA, PRO, SP16/421/152.

27 TNA, PRO, PC2/49 p. 145. Prynne commented that 'the church yet must not be used for a Church, because not consecrated by a Bishops conjuring white Rochet': William Prynne, A quench-coale (1637), p. 236. 
over-populated existing parish, and the question of lay control over the appointment of the new minister also emerged. Laud's erstwhile patron, Archbishop Neile, refused to consecrate the newly-built church in 1633 when the church's patron proposed that the new minister be nominated by a panel of ten aldermen. Neile's eventual partial victory in ensuring that the vicar of Leeds would retain authority over the new minister and have an input into his appointment may well have encouraged Bray and Laud to hold out for similar conditions in Covent Garden, although that stalemate lasted considerably longer (the Leeds case was resolved in a year). ${ }^{28}$ Laud himself had taken a similar stand in 1629 before consenting to the building of a new chapel of ease in Hammersmith (which he consecrated in 1631). Here he had not only upheld the rights of the existing vicar, but had refused to yield to proposals that the inhabitants would submit a minister for his approval (or even a number of ministers for him to select from) and had insisted that he would make the appointment himself and would not 'give way to any popular nomination'. ${ }^{29}$

The stalemate in Covent Garden was only broken in 1638, when more than a hundred inhabitants of the area petitioned the Privy Council to resolve the problem so that a preaching minister could begin to serve in the church. ${ }^{30}$ The petition secured its

${ }^{28}$ R. A. Marchant, The puritans and the church courts in the diocese of York 1560$\underline{1642}$ (1960), pp. 116-17. I am grateful to Ken Fincham for drawing this parallel case to my attention.

${ }^{29}$ Laud, Works, III, p. 213; VII, pp. 25-6, 31. See also TNA, PRO, SP16/153/70. Compare also Bishop Bridgeman's curbs on lay appointment to the new chapel of Ringley before his consecration of it in 1634: J.S. Fletcher, The correspondence of Nathan Walworth and Peter Seddon (Chetham Society, 1880), p. 30.

${ }^{30}$ TNA, PRO, PC2/49 p. 145. 
aim of a full hearing of the matter before the Privy Council on 6 April 1638. Bedford was personally present and the King himself presided, passing the final judgement. The account of the hearing occupies no less than four pages of the Privy Council register. ${ }^{31}$ Bedford argued that he had built the church and a dwelling house for the minister, and guaranteed to provide a generous income of $£ 100$ a year for the incumbent. Given this outlay, he considered it to be 'of Common Course and in all equity' that he should control the appointment to the living. Bray (doubtless primed by Laud) insisted that until Covent Garden obtained separate parochial status by act of parliament he still retained the right to appoint the minister, whose stipend Bray ultimately offered to pay in the meantime.

It was finally resolved by the king that Bray should appoint and pay the curate until an act of parliament made Covent Garden parochial (giving his 'Royall and forerunning assent' to such a future bill). Once the act was passed, though, Bedford would thereafter be granted the right to appoint and pay the minister on the grounds of 'his voluntary Bounty and devotion to the Service of God'. ${ }^{32}$ In the meantime, Bray retained temporary control over the new church, and duly appointed two nonentities to the curacy in quick succession. ${ }^{33}$ Nevertheless, the king's judgement was still a minor setback for Laud, who was always anxious where possible to restrict the rights of laymen to appoint ministers, and would now have a new lay-funded minister appointed by the puritan-connected Bedford, based very close to the court. In the end,

\footnotetext{
${ }^{31}$ Ibid., pp.145-8.

${ }^{32}$ Ibid., pp. 146-8.

${ }^{33}$ Samuel Porter MA was appointed on 6 October 1638 and Francis Hall on 4 April 1640 (G. Hennessy (ed.), Novum repertorium ecclesiasticum parochiale Londinense (1898), p. 366).
} 
perhaps Charles trusted a fellow-aristocrat to make the right appointment, and his esteem for the nobility overcame Laud's fears for the church. It is also possible that, given the many extra burdens and restrictions that he had placed upon Bedford's development, Charles felt that he could not really impose any more. Of course, it was also the case that in 1638 the king was in no hurry to call a new parliament.

One final point the king had urged was that the church be consecrated as soon as possible, but it was almost another six months before this occurred. In the meantime there were a series of no less important practical matters that needed to be agreed relating to the organization of the new parish-in-waiting at Covent Garden. Even so, it was only the day before the consecration that a set of 'articles of agreement' relating to the chapelry were accepted by the earl of Bedford and the vicar and by inhabitants of the existing parish of St Martin in the Fields -- all in the presence of the bishop of London's chancellor. ${ }^{34}$ The fact that this was so close to the consecration suggests a good deal of last-minute negotiation, and (as we will see) the articles would be challenged soon afterwards. But finally, on 27 September 1638, Bishop Juxon consecrated the church of St Paul Covent Garden, with Bray giving the sermon and his fellow-chaplain William Haywood in attendance. ${ }^{35}$

\footnotetext{
34 The articles included agreement on the chapelry boundaries (to include Bedford House), the choice of chapelwardens, the devising of local rates, attendance at communion services in each others' churches; the maintenance of the preacher, the repair of the chapel, and the payment of oblations and tithes. The only copy of these articles that appears to survive is in B[ritish] L[ibrary], Harl. MS 1831 fos. 28-9. ${ }^{35}$ BL, Harl. MS 1831 fo. 32v.
} 
The consecration of the church and signing of the articles of agreement did not, however, mark the end of the disputes surrounding the new precinct. It was in Covent Garden itself that Bedford encountered his next opposition. Bedford's ambitious plans and occasionally peremptory behaviour, as well as his very close personal involvement in negotiating individual leases, ${ }^{36}$ soon led to fallings out within the new precinct. Moreover, those inhabitants of St Martin's who had hoped for a new chapel of ease had ended up with a new church devised by Bedford as his own parish church, while those living there now faced being hived off into a separate parish.

Just two months after the 1638 consecration, resentment at Bedford took the form of a petition to King Charles against the earl. This petition was signed by some eighty-seven people, who declared themselves to be 'the Parishioners of St Martin in the Feildes Inhabiting in that parte of Covent Garden now assigned to the new Chappell there'. ${ }^{37}$ Right from the petition's opening words, the petitioners were anxious to deny that the building of Covent Garden church had been the selfless act of a charitable donor, or had originally been intended to create a new parish. Rather, they stressed, the church had been meant to serve merely as a chapel of ease for St Martin's, the mother church. Bedford's involvement, they insisted, had been anything but altruistic. Bedford's promise to the king to build the church, the petitioners declared, was merely an 'Argument used by him' to persuade the king to grant him a

\footnotetext{
${ }^{36}$ See Alnwick Castle, Y.III/2/1-3a passim. Note also petitions against Bedford for nuisances arising from Covent Garden: e.g. L[ondon] M[etropolitan] A[rchives], WJ/SR (NS), 46/11 (May 1636).

${ }^{37}$ TNA, PRO, SP16/402/75.
} 
license to build houses in Covent Garden. At the heart of the petition were the sums that it was feared that the inhabitants of the chapelry were being required to pay to cover the costs of Bedford's failure (as they saw it) to honour his obligations towards the church. Among other things, it was complained that the roof and other parts of the church had been defectively built, so that they could not be timbered and leaded properly for less than $£ 1500 .{ }^{38}$ But their principal complaint was that Bedford was seeking to claw back money that he had spent on the interior of the church. Thus it was objected that Bedford had built an altar, font, pews, pulpit 'and other necessaries' for the chapel but was now demanding nearly $£ 1200$ from the parishioners in payment for this. And this despite the fact that Bedford had 'freely given them to the service of God, and procured the Consecration of them'. This all added up to a sum of over $£ 4000$, charged to the inhabitants of the chapelry. The petitioners urged the king that they should not be required to pay for things that had already been given and consecrated to the church. The petitioners also sought to demonstrate their own loyalty to the crown (and, implicitly, Bedford's lack of the same) by pointedly complaining that Bedford had promised that he would erect 'A beautiful Structure' in the centre of the piazza on which he would place a statue of Charles I in brass, surrounded by a fair iron gate, which he had failed to do. ${ }^{39}$

\footnotetext{
${ }^{38}$ This would seem to have been true. For references to the roof being in danger of falling down, and the need to raise sums to repair it in the early 1640s, see TNA, PRO, C3/424/13, C6/125Pt1/1. They also complained that they would have to build a steeple with clock and bells for the chapel (noting scornfully that lacking a steeple and bells the chapel could hardly be called a church) and that this would cost 2000 marks - a task that Bedford should have performed.

${ }^{39}$ TNA, PRO, SP16/402/75.
} 
Not the least intriguing aspect of the petition is the glimpse that it provides of promises and assurances made by Bedford 'and his Officers' towards the builders and leasees of the development. These included not only the frame for the statue of Charles, but also an alleged promise by Bedford to pave the piazza and to enlarge the narrow passage onto the high street. The petition's claim that Bedford had proposed to build the church merely as a way of extracting from the king a license to build houses presumably reflects local knowledge of the warrant drawn up in 1629. It is certainly possible that some of the 'many inhabitants' who had accompanied Laud and Montford in making overtures to Bedford for land for a chapel of ease had been privy to subsequent negotiations and promises on Bedford's part. The reflections in the petition may also indicate the degree to which a popular 'memory' of the negotiations had already been generated, in which Bedford was understood to have made promises that had never been fulfilled. Interestingly, this sense that Bedford had reneged on earlier agreements would inform disputes in the parish right through to the Restoration period (as we will see).

It is also important to note the signatories to this comprehensive indictment of the earl. Soon afterwards it was dismissively claimed that they included 'some few gentlemen' but that the rest were mere 'Tradesmen'. ${ }^{40}$ This is borne out by the signatures: there were women as well as men, and some only signed with a mark. Nevertheless, despite attempts to denigrate the social status of the petitioners, these craftsmen and tradesmen were hardly simple folk, and included men such as Peter Le Huc, who worked on the scenery for court masques. ${ }^{41}$ The poor rate records also

\footnotetext{
40 TNA, PRO, SP 16/402/75/IV.

${ }^{41}$ Le Huc was paid $£ 50$ for repairs to the scenery and 'property' for the play 'The Royall Slave' (TNA, PRO, SO3/11 Apr. 1637).
} 
demonstrate that many of these petitioners were reasonably prosperous: in the 1637-8 poor rate, of forty-two petitioners listed, half were rated at $8 \mathrm{~s} 8 \mathrm{~d}$, and fourteen more at higher sums, with two signatories rated at an impressive $26 \mathrm{~s} .{ }^{42}$ There was only one signatory who had been involved in developing Covent Garden property with Bedford - and this was one George Hulbert. Hulbert was a prominent figure in local society and a Westminster JP, who was also a member of the Westminster Court of Burgesses and one who had played a leading role in the locality during the 1636 plague epidemic. The petition's reference to what Bedford had promised to 'the first undertakers and builders of the Covent Garden for their encouragement in the said worke' was therefore presumably Hulbert's insertion, and implies that (as was clearly suspected) he was the main orchestrator of the petition itself. Certainly, Hulbert had been involved in contentious petitioning before, when he had signed a 1621 petition objecting to the dean of Westminster's conduct of local elections. ${ }^{43}$ Hulbert had also clearly tussled with Bedford personally over the provisions of his own leases in Covent Garden. Surviving drafts of the leases are peppered with his amendments and whole pages of crossings out - and he may well have been left unsatisfied. ${ }^{44} \mathrm{He}$ certainly seems to have been a natural figure to have devised the petition against Bedford, then. It may not be coincidental that at the height of the controversy over the petition, in early 1639 Hulbert went to the trouble of securing a coat of arms for himself, the docket of which notes his local offices as the herald explains that the

\footnotetext{
${ }^{42} \mathrm{WAC}, \mathrm{F} 364$.

${ }^{43}$ Surrey History Centre, LM/1989; Merritt, Social world, pp. 97 n115, 124, 342

n.169.
}

${ }^{44}$ Alnwick Castle, Y.III/3a/3 (a bundle of papers, including an indenture dated 20 Feb. 7 Charles I). 
award is made 'taking into consideration these signs of speciall trust and Credit which he beareth in the Common Wealth'. Whether or not Hulbert perceived himself as defending the local 'Common Wealth' against Bedford he was clearly determined not to be overawed by his social superior, and may well have been trying to establish his own authority in the new precinct, given his previous prominence in St Martin's. ${ }^{45}$ But does the petition therefore simply represent Hulbert's manipulation of his fellowparishioners? There is no need to see things in this fashion. Hulbert may have exploited fears over Bedford's intentions, but there seems no reason to doubt the parishioners' genuine concerns that they could be compelled to pay more than $£ 4000$ in rates to fund the shortfall in Bedford's expenditure on the church.

Whatever the precise objectives behind the petition, the petitioners seem to have expected a sympathetic hearing, knowing that the king himself had shown little reluctance in prosecuting Bedford in the courts. Indeed the petitioners tried to suggest that the king had been misled by Bedford, a man who had sought to wriggle out of his promises. The petitioners may also have hoped for Laud's support against the earl they certainly voiced a keen (though admittedly self-interested) esteem for the rite of consecration and the inviolability of the church's furnishings.

But if these indeed were their hopes, the petitioners were sadly mistaken. The king non-commitally passed what might be termed this 'anti-Bedford' petition on to Laud and Bishop Juxon of London, who arranged an initial hearing with all those concerned. ${ }^{46}$ From this first meeting (on 12 December 1638) emerged some remarkable directions that focused not on the charges against Bedford, but on the character of the petition itself. Laud and Juxon directed that the 'vestry' of the Covent

\footnotetext{
45 TNA, PRO, SP16/413/129.

${ }^{46}$ TNA, PRO, SP 16/402/75/I, II.
} 
Garden chapelry should meet to consider the signatures to the petition and identify how many 'of the best of the said Inhabitants who are householders' had subscribed to the petition and approved it, and how many had been 'contractors' for leases with Bedford. They were also - remarkably -- charged to compile a list of names of all those who had not subscribed to the petition. ${ }^{47}$ The result was an extraordinary exercise in assessing the validity of the petition's claim to speak for the area's inhabitants, by listing all those who had not subscribed, arranged (significantly) in columns according to their social status. This list contains some 270 inhabitants, including three earls, five lords, nine knights and many tradesmen. ${ }^{48}$ It is possible that Laud and Juxon were the ones expressing concern that the petition was a factious and scandalous one. But it seems most likely that it was Bedford himself who chose to respond to the accusations by focusing on the petition itself, and by questioning not just its representativeness, but also the social standing of the petitioners. The question of who precisely should be deemed to represent the opinion of the new precinct would be a major issue of contention during the next few years, but it is interesting to note the future parliamentarian hero Bedford associated with such a hostile posture towards popular petitioning.

Moreover, it is worth examining the names of those who signed the supposed 'vestry' report on the Bedford petition. Laud and Juxon wrote to the 'vestry' of the chapel of Covent Garden on the matter, but in theory no such body existed. The 'articles of agreement' that established the chapelry refer only to the existence of chapelwardens and overseers of the poor who 'shall have power to dispose of their Chappell business and all affaires thereunto belonginge', although they also note that

\footnotetext{
${ }^{47}$ TNA, PRO, PC2/49 p. 598.

${ }^{48}$ TNA, PRO, SP16/402/75/IV.
} 
a 'competent number of the inhabitants' might work with St Martin's parishioners in drawing up any rates that were levied on both the chapelry and mother church. ${ }^{49}$ Such a 'competent number' seems to have been assembled soon after the consecration of the chapelry, but to organize a rate levied purely on chapelry inhabitants. Fifteen named inhabitants (in addition to Bray) were instructed by an episcopal commission dated 3 November 1638 'to meete together in the vestriehouse of the sayd chappell' to rate all the inhabitants to pay for the new church ornaments, vestments 'and other utensils' ${ }^{50}$ If this was the 'vestry', then it is remarkable that soon afterwards three of its members signed the anti-Bedford petition (including Hulbert himself). ${ }^{51}$ The 'vestry' that reported on the petition was a very different body indeed. Only four of the fifteen men who had been named on the rating commission also signed the petition report, and all of these four were close to Bedford. They included Bedford's agent Robert Scawen, Anthony Wither (a resolute defender of the notorious puritan Thomas Foxley) and Edward Carter (Inigo Jones's deputy, who actually signed the building accounts for Covent Garden church). ${ }^{52}$ It is notable that Carter and Wither were later entrusted by Bedford not only with collecting pew rentals owing to the earl, but also with allocating pews (presumably after consultation with him) ${ }^{53}$ It seems

\footnotetext{
${ }^{49}$ BL, Harl. MS 1831 fo. $28 \mathrm{r}-\mathrm{v}$.

${ }^{50}$ LMA, DL/C/344 fos. $48 \mathrm{v}-49 \mathrm{r}$.

${ }^{51}$ The other signatories were Thomas Brett and Francis Layton.

52 TNA, PRO, SP16/402/75/IV. John Chicheley was the fourth man, for whom see below, n. 95 .
}

${ }^{53}$ See a copy of their commission (granted by Juxon on 23 July 1639, and confirmed later by Laud and Juxon in the face of local challenges) in BL, Harl. MS 1831 fo. 38rV. 
plain, then, that the 'vestry' that drew up the report on the anti-Bedford petition was a partisan collection of Bedford supporters (including the earl's son-in-law Lord Brooke), whereas other prominent parishioners had either signed the anti-Bedford petition or refrained from direct involvement in the report on their fellowparishioners. ${ }^{54}$

The petition's charges were finally dealt with at a further hearing the following May, 1639 where the result was a complete defeat for the petitioners. ${ }^{55}$ It was concluded that the petition against Bedford was 'verie scandalous and untrue in many things', and the petitioners were berated for the injury they had done the earl in 'causelessly' petitioning against him. The petitioners were ordered immediately to fulfil their part of an earlier agreement that had allegedly been made by the parishioners with the earl of Bedford by paying the sums demanded of them. ${ }^{56}$ Attention was particularly focused on the pews, which seem to have been the real cause of contention. The chancellor of London diocese testified that it had been agreed by the earl and the inhabitants of the chapelry before the consecration that Bedford 'shall have power to dispose of the said pewes unto the inhabitants of Coven Garden and to compound with them for the same for the tearme of their lives'. ${ }^{57}$

\footnotetext{
${ }^{54}$ See below, n. 78 .
}

55 This meeting was very different to the Privy Council hearing of the previous year. This time the matter was only dealt with by Juxon and Laud, meeting in 'the Inner Starchamber' with Bedford and the petitioners with their counsels. TNA, PRO, PC2/50 pp. 367, 381 .

${ }^{56}$ Ibid.

${ }^{57}$ See the extract from the bishop of London's register in TNA, PRO, SP16/421/154. This entry is no longer extant in the surviving register (GL, 9531/15) which only 
So the 'anti-Bedford' petition failed. But why did Laud seemingly not support this petition against Bedford? After all, the archbishop would presumably have sympathized with complaints that an overbearing aristocrat was trying to extort money for things that had been freely given and consecrated to the church. There are several possible reasons for Laud's lack of support. He may have felt that the authority of the church was less bound up in the case, which was more to do with parishioners seeking to avoid financial charges. In addition, the inhabitants of Covent Garden had recently shown themselves very reluctant to contribute towards the cost of new plate and vestments for the would-be parish. Laud's chaplain Bray, as vicar of St Martin's, had been required to provide these for the new church and the apparent cost (over £300) suggests the richness of the 'ornaments' selected. At the hearing of the anti-Bedford petition, though, it was reported that most of this money had not been collected, despite Bray having been granted a commission to charge a rate on the chapelry the previous November. All the inhabitants were ordered to pay this rate, and the collectors were instructed to return the names of all those who refused to pay. ${ }^{58}$ This response would obviously have made Laud less likely to view the petitioners as sincere upholders of the rights of the church. Finally, even if Bedford had been a

contains a fraction of its original material. The agreement over pews does not seem to survive (the pewing arrangements are not mentioned in the copy of the 'articles of agreement' in BL, Harl .MS 1831 fos. 28r-29v, which are only concerned with relations between the chapelry and the parish of St Martin's). It is impossible to tell from surviving allusions to it what were the precise circumstances in which this pewing agreement was made (and -- most importantly -- which parishioners signed it).

${ }^{58}$ TNA, PRO, PC2/50 p. 381. 
threat to the church in the past, an impertinent attack on the peerage could have prompted Laud to feel that the authorities should close ranks. After all, Laud had reasons to distrust the laity of St Martin's, whose choice of lecturers had given him some trouble in the recent past. ${ }^{59}$ It also seems likely that Laud had been lobbied intensively by Bedford in this matter. Clarendon's later report that Bedford 'frequently visited and dined' with Laud has often been noted by historians, with the implication that the two enjoyed amicable relations. ${ }^{60}$ The sustained five-year standoff between Bedford and Laud's chaplain is difficult to reconcile with any suggestion that the earl and archbishop had enjoyed a close friendship before 1638. It may be true, however, that in the late 1630s Bedford regularly visited the archbishop to solicit his support over the petition, to provide much-needed reassurance over the Covent Garden project, and presumably to depict his enemies in the precinct as dangerous subversives. The case was clearly not an easy one, though, and Juxon's and Laud's judgement went through no less than four drafts, rejecting the charges of the 'antiBedford' petitioners, but also removing a generous clause that stated that in all the disputed financial matters 'Wee hold it most just and fit to leave the said earl at liberty to doe in these particulars as shall seeme good to his Lordship'. ${ }^{61}$

\footnotetext{
${ }^{59}$ See above, p. 00.

${ }^{60}$ Earl of Clarendon, The history of the Rebellion and Civil Wars in England, ed. W. Macray (6 vols., Oxford, 1881), I, pp. 308-9; Duggan, 'London the ring', p. 149. It should be noted that Laud was strikingly hostile towards the earl in 1641, seeing Bedford's death just before the royal assent was given to the bill of attainder against the earl of Strafford as God's judgement upon him as 'one of the main plotters of Strafford's death ... [who had] resolved to have his blood' (Laud, Works, III, p. 443). ${ }^{61}$ TNA, PRO, SP16/421/150-153.
} 
The judgement of Laud and Juxon, however, was not an end to strife in Covent Garden. This partly reflected the many ambiguities associated with the creation of a chapelry as a sort of parish-in-waiting until an act of parliament could formally establish a new parish. It was soon objected that the creation of the chapelry had essentially been the work of an unrepresentative minority. A lawyer acting for St Martin's complained to the Privy Council in 1640 that the inhabitants of St Martin's and Covent Garden who had agreed and subscribed to the 'Articles of agreement' the day before the consecration 'were but few in respect of those who were absent', and that these articles agreed 'in the name of the residew' were invalid. ${ }^{62}$ The fluctuating membership of St Paul's so-called 'vestry' could also have prompted concerns over its representativeness, and the dominant role being played by Bedford's clients. It is clear that not everyone in the locality was prepared to accept this ad hoc chapelry government. Indeed, some went so far as to have their own independent meetings and to resist the authority of the chapelry officers. It was complained in 1640 that a faction in the parish 'doe also without authority summon and hold unlawfull meetings resiste the officers in the church, \& clyme over pewes'. It is particularly notable that these plaintiffs in 1640 identified this resistance with the 'tradesmen' who had been involved in the earlier petition against Bedford. ${ }^{63}$

Once again the issue of church seating particularly inflamed passions. It was complained that many of the pews had not been allocated because of "the dissension

62 TNA, PRO, PC2/52, p. 638. The Privy Council rejected this objection because of 'the severall sufficient warnings given by authority from the lord Bishop of the Diocess, to the whole Parish, to bee there present'.

${ }^{63}$ TNA, PRO, SP16/458/15 (a copy of which is in BL, Harl. MS 1831 fos. 35v-36r). 
of the inhabitants'. ${ }^{64}$ Not only were many parishioners still unwilling to pay, but it was complained in 1640 that some of them 'did violently intrude and seate themselves in Pewes in the said Chappell without being placed there orderly by those Authorized in that behalfe'. ${ }^{65}$ Again, the authority of chapelry officials was being denied. Other inhabitants seem to have simply decided to give up on the issue, returning to $\mathrm{St}$ Martin's church where they had retained their pews, and prompting an order from Laud and Juxon that they should 'bee not permitted to Continue their Pewes any longer theare but to repayre to the said Chappell'. ${ }^{66}$ Ultimately, the issue of pewing may not have been simply a financial one. It was the allocation of pews that was just as important. In a new locality, church seating was one of the quickest ways of displaying, and in a sense creating, the new local hierarchy. ${ }^{67}$ Yet clearly some felt dissatisfied, particularly if the matter seemed to be dealt with not by representatives of

\footnotetext{
${ }^{64}$ BL, Harl. MS 1831 fo. 38r.

${ }^{65}$ TNA, PRO, PC2/51 p. 329.

66 Ibid.
}

${ }^{67}$ On pewing and social status, and the controversies that this could often generate,

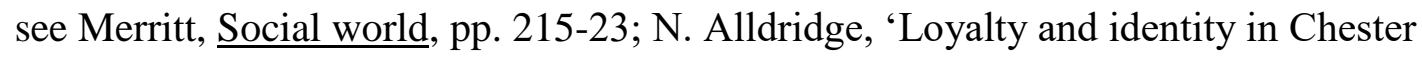
parishes 1540-1640', in S. J. Wright (ed.) Parish, church and people: local studies in lay religion, 1350-1750 (1988); J.P. Boulton, Neighbourhood and society (Cambridge, 1987), pp. 146-7, 286-7; A. Flather, The politics of place: a study of church seating in Essex, c.1580-1640 (Leicester, 1999); P. Griffiths, Youth and authority (Oxford, 1996), pp. 104-9; C. Marsh, 'Order and place in England, 1580-1640: the view from the pew', Journal of British Studies xliv (2005); C.W. Marsh, 'Sacred space in England, 1560-1640: the view from the pew', Journal of ecclesiastical history liii (2002); M. McIntosh, A community transformed (Cambridge, 1991), pp. 199-201. 
the parish, but by clients of the earl. It is interesting in this context to note that Bedford had earlier tried to sell his pew in St Martin's church without any reference to parish officials - perhaps he saw pews as little more than a commodity, which could be exchanged without reference to local authority. ${ }^{68}$ In this case, however, Laud and Juxon, at a further hearing, supported Bedford and insisted that the pewing arrangements should be observed within the chapelry. On this occasion the dissenting inhabitants had done themselves no favours by continuing in their refusals to pay Bray for the new plate and vestments, despite his commission to rate them for the sum. The pewing disputes and the resistance to paying for church ornaments were discussed at the same hearing, and once again Laud seems to have been convinced that the anti-Bedford elements in the chapelry were forces of disorder in need of discipline rather than support. ${ }^{69}$

In the meantime, financial struggles emerged between the 'chapelry' of $\mathrm{St}$ Paul Covent Garden and the mother parish of St Martin's. Given that the creation of the chapelry had geographically hived off some of St Martin's wealthiest ratepayers, the need to retain their rates was acute, especially in the wake of the financially

\footnotetext{
${ }^{68}$ WAC, F2002 fo. 106 (1636); Merritt, Social world, p. 219.

${ }^{69}$ TNA, PRO, PC2/51 p. 329; BL, Harl. MS 1831 fo. 39r. 'Divers of the Inhabitants of the Covent Garden' who were then summoned before the Privy Council on 6 March because of their non-payment of the rate claimed that they were ready to pay, but were unhappy about rating technicalities, arguing either that they had been overrated or that they were only temporary residents: TNA, PRO, PC2/51 p. 342.
} 
devastating 1636 plague. $^{70}$ The dispute resulted in some bizarre practices, including occasions when St Martin's overseers of the poor were instructed by their vestry simply to stand at the chapel doors of St Paul's to collect the sums allegedly due to them. ${ }^{71}$ Similarly, Covent Garden officials later admitted that money they had collected for their own poor was falsely listed in accounts as money to repair the church roof, simply to keep the funds from St Martin's. ${ }^{72}$ When the dispute was at its height, several JPs ordered the imprisonment of two Covent Garden officials on two separate occasions. The officials had been appointed by St Martin's JPs to serve as overseers of the poor in what was clearly an attempt to gain control of the sums being raised in Covent Garden for poor relief, and were imprisoned for refusing to serve. Supporters of the imprisoned officials complained that the JPs concerned were in effect acting as officers of St Martin's parish vestry, and that on both occasions they had committed the hapless Covent Garden men to prison while 'sitting in their vestrie at St Martins church'. ${ }^{73}$ The officials were released the first time by a counter-order of three JPs who were resident in Covent Garden (one of whom - Sir Edmund Verney was one of Bedford's contractors). Even the bench of Westminster justices was thus split between St Martin's and Covent Garden. ${ }^{74}$

${ }^{70}$ In 1636-7 St Martin’s expenses had soared to a staggering $£ 1406$, more than double the yield of the parish's combined plague and poor rate: Merritt, Social world, pp. 298, 305-6.

${ }^{71}$ WAC, F2002 fo. 130.

72 TNA, PRO, C6/125(1)/1; Survey, pp. 53-4.

${ }^{73} \mathrm{H}$ [ouse] of L[ords] R[ecord] O[ffice], Main Papers 25 Feb. 1641.

74 This charge was somewhat unfair. One of those named - Sir Selwyn Parker - was paying rates in King Street Covent Garden 1639-43, so was clearly a Covent Garden 
The jurisdictional and financial issues here are clear, but this was not simply a quarrel between the new chapelry and the old parish. Rather, these disputes also reflected the power struggles within the new chapelry. It is striking, for example, that the petition to the king appealing for the release of the two Covent Garden officials was signed only by the two officials themselves and Anthony Wither 'in the name of the inhabitants in Covent Garden' but, a contemporary copy icily adds, 'without their consents'. An anti-Bedford thread ran through these disputes as well. Not only were Bedford associates particularly targeted, and even subjected to arrest, but it seems clear that not all inhabitants of Covent Garden backed the imprisoned chapelry officials. Indeed previous anti-Bedford petitioners within the chapelry apparently encouraged St Martin's officials to act. According to one report, the problem lay with 'divers tradesmen inhabitants within the Chappell beinge of violent \& factious spirittes formerly censured by the Lords of your majesties councell for their ... behaviour towards some of the nobility'. As they were themselves opposed to the chapelry's 'articles of agreement', so they 'stirred upp some of St Martins parish to attempt to breake through their part of the articles'. ${ }^{75}$

resident rather than simply a St Martin's JP. One anonymous JP also refused to sign the warrant releasing the officials (Richard Harris and Josias Fendall), and wrote a self-defence (copy in BL, Harl. MS 1831 fo. 35r) in which he emphasized that the officials concerned had been appointed overseers by JPs and not by the St Martin's vestry.

${ }^{75}$ BL, Harl. MS 1831 fo. 35v. It is clear that it was Bedford's men who were being targeted. A petition appealing for their release a second time - again in the name of 'the Inhabitantes within the precinct of the Chappellry of St Pauls Covent Garden' -- 
The formal creation of a new parish by act of parliament was an obvious way of resolving some of these difficulties, and with the calling of the Long Parliament this finally became a possibility. But even here there were two separate bids for parochial status. Bedford himself seems to have devised a draft bill by December $1640 .^{76}$ Yet other inhabitants seem to have sent a very different petition to parliament around the same time for Covent Garden to be made into a parish. This petition seems to have been partially couched in terms antagonistic to the earls of Bedford. According to one account, the petitioners argued that Bedford had failed to build a proper church, and they complained of the unfair rates levied for pews. ${ }^{77}$ The creation of a parish of Covent Garden was clearly hoped to be the means by which opponents of Bedford would be empowered in local affairs, freed from the domination of one individual and his clients. It was later claimed by the petitioners that they wished Covent Garden to be a parish so that it could enjoy "parochial privileges and liberties for the good of the inhabitants'. This bid for parochial status would seem to have been the work of an alternative, would-be body of parish governors, who had hitherto

is also signed by the familiar Bedford names Wither and Carter as well as four other of Bedford's leasees (and Lord Brooke): HLRO, Main Papers 25 Feb. 1641.

${ }^{76}$ Woburn Abbey, Muniments of Title, Middlesex, G, bundle 2, no. 1; Survey, p. 54. It is alleged in the February 1641 petition for the release of the Covent Garden officials that the St Martin's JPs had acted 'perceiving that his Majesties royall assent is promised in this Parliament for making the said precinct parochiall \& a Bill allreadie preferred to that purpose' (HLRO, Main Papers 25 Feb. 1641).

77 This was claimed by one of the petition organizers, William Clifton, but was denied in a submission to chancery by his colleagues, who insisted that the petition was not directed against the earl: TNA, PRO, C3/424/13. 
played only a limited role in parish affairs and had been notably absent from Bedford's circle and its activities. They included three signatories of the anti-Bedford petition. It is equally striking that none of Bedford's supporters, and none of those who signed the petition for the release of Covent Garden officials in 1641, were involved were involved in this alternative bid for parochial status. ${ }^{78}$

The Long Parliament was thus presented in early 1641 with two different bills for making the Covent Garden chapelry parochial. After one of the bills had been read the other bill was read a few weeks later, with the explanation that the earlier bill 'was mistaken' (although as it transpired neither bill reached a third reading). ${ }^{79}$ Such conflicting petitions encapsulate just how divided and dysfunctional the would-be parish was.

${ }^{78}$ The petition itself does not appear to survive. Of the eight men reportedly involved in it, three of them had signed the anti-Bedford petition (Henry Coveney, William Clifton and John Haulton) while another three had been members of the earlier 'vestry' commissioned to levy a rate (John Honor, Thomas Constable and George Norfolk). The latter three, while they had not signed the anti-Bedford petition, had not signed the 'vestry' report on the petition either, or the petitions in favour of the imprisoned chapelry officials. Honor and Constable had allegedly at one point been chosen as chapelwardens but prevented from taking up their positions. Along with Coveney, they had also been among the eight chapelry inhabitants who signed the 'articles of agreement' with St Martin's parish in September 1638: TNA, PRO, C3/424/13; C6/125pt.1/1; SP16/402/75; BL, Harl. MS 1831 fo. 29v; LMA, DL/C/344 fo. 49 r.

${ }^{79}$ Proceedings in the opening session of the Long Parliament, ed. M. Jansson (6 vols., Rochester, N.Y., 2000-05), II, 388, 623. 
The lack of surviving parochial records means that the picture remains frustratingly incomplete in some of its details, yet it is clear that clashes between Bedford and his clients on the one hand, and opposing groups within Covent Garden on the other, became entrenched in the later 1630s and stretched well into the 1640s. In the event, Covent Garden had to wait for its final establishment as a separate parish until 1646, when parliament had finished with its other business of winning the civil war. By then, the introduction of the presbyterian system meant that some of the anomalies of Covent Garden's government were resolved. ${ }^{80}$ And interestingly, the thirty-four 'governors' established to run the parish in 1646 included not only the new earl of Bedford (the only nobleman listed), but also men who had featured on both sides of the earlier disputes, although no one described as below the rank of 'gentleman'. ${ }^{81}$ Nevertheless, power struggles and alleged social divisions among prominent parishioners continued to dog the new parish well into the $1650 \mathrm{~s} .^{82}$

Divisions emerged again at the Restoration, when an act of parliament had to be secured to confirm the parochial status established by the 1646 ordinance. A petition from 'the inhabitants' of St Paul Covent Garden to the House of Lords pleaded that the ordinance should not be confirmed. Signed by some fifty-nine inhabitants (some of whom signed with a mark, and none of whom were gentry) the petition claimed that the ordinance had been procured in 1646 'by some perticular persons', and that it was now being presented to parliament by 'perticuler persons without the Consent of the Major partie of the said Precinct'. Covent Garden, they averred, was part of St Martin's parish 'and therefore the Inhabitants thereof are Tithe

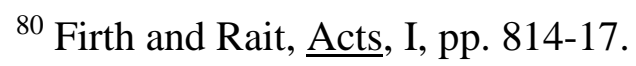

${ }^{81}$ Ibid., I, p. 815.

${ }^{82}$ See my Westminster and the English Revolution (forthcoming).
} 
Free and soe liable to noe other taxations or Rates then are the rest of the said parish[,] The Earle of Bedford being bound to Endowe it'. ${ }^{83}$ The story of how an unrepresentative clique had created the parish, and the earl of Bedford had reneged on his obligations to pay for it, had clearly become well established in the local popular memory.

III

The conflicts in Covent Garden point to a number of broader conclusions about the workings of religious patronage and local communities and the intersection of local and national politics in this period.

One recurring issue in the creation of the new parish was the role played by the earl of Bedford as its patron. Bedford was seeking to build his own power base in the locality, with his clients, trusted contractors and relatives effectively running the precinct, while he himself controlled the living, appointing and paying the minister of his choice. Here was the aristocratic dominance of a parish of the sort that we associate more with provincial parishes and the local manor house - yet St Paul Covent Garden was in the heart of the metropolis. But if Bedford was indeed seeking to create his own parish, linked to his private London townhouse, he was also a commercial developer, and this provides an important dimension to the quarrels. The traditional rhetoric surrounding donations to church fabric emphasized the pious and

\footnotetext{
${ }^{83}$ HLRO, Main Papers 13 Dec. 1660, item 9.
} 
communal intentions of the donor ${ }^{84}$ Within the locality, the patron of an entirely new church could thus expect honour and prestige in return for his generosity. Bedford perhaps wanted honour among the godly and prestige for architectural innovation from the court. But for the inhabitants themselves, Bedford gradually appeared more in the guise of a developer rather than a charitable donor, seeking to claw back the maximum cash from his own leasees and their tenants for his initial outlay. Informal ties of honour, respect and reciprocity may have been subtly undermined. The outraged response of some inhabitants may reflect partly a confusion of expectations (and a local 'memory' of what Bedford had promised to do) but also the peculiarity of the project. In London, when a church was refurbished or rebuilt, this was usually envisaged as a community project, where many of the furnishings and ornaments of the church were provided by parishioners as charitable contributions. ${ }^{85}$ Similarly, rents from pews, which at Covent Garden went directly to the earl of Bedford, were more usually collected for the benefit of the parish (indeed, in the nearby Broadway chapel the pew rents were used to help pay for the minister). ${ }^{86}$ But the perception seems to have grown that this was Bedford's parish and Bedford's church, with rates collected by Bedford's men, with the result that local inhabitants seem to have been somewhat detached, and unwilling to donate towards church furnishings.

The struggles in Covent Garden may also reflect broader social tensions. This was an area with unusually high numbers of aristocratic and gentry residents, but their

\footnotetext{
${ }^{84}$ I. Archer, 'The arts and acts of memorialization in early modern London' in J. F. Merritt (ed.), Imagining early modern London (Cambridge, 2001), pp. 102-113;

Merritt, 'Puritans', pp. 945-7; Merritt, Social world, pp. 213-14.

${ }^{85}$ Merritt, 'Puritans', pp. 946-50.

${ }^{86}$ Lambeth Palace Library, COMM.XIIa/12, p. 380.
} 
social status was not necessarily reflected in the power and influence that they wielded in the locality. Indeed, in St Martin's parish, out of which Covent Garden was carved, by the 1630 s gentlemen were becoming less prominent on the parish vestry, which largely consisted of wealthy members from the service sector. In parish society there were alternative hierarchies of local status, office-holding, and length of residence that ran alongside the more universally recognised gradations of social status. ${ }^{87}$ By contrast, it is notable that in the response to the anti-Bedford petition, and in the complaints of the imprisoned Covent Garden officials in 1641, the opponents of Bedford's agents in the chapelry are persistently and pejoratively identified as 'tradesmen'. ${ }^{88}$ This injected an air of social exclusivity into the running of the wouldbe parish which was notably different to that which had pertained in the mother parish of St Martin's. In creating his new parish, Bedford (an erstwhile St Martin's parishioner) was effectively constructing a new local hierarchy linked to his own prominence, overseeing the symbolic expression of that hierarchy through his allocation of pews, and having parish business run via his clients on the 'vestry'. There was nothing new in a single aristocrat wielding influence in the area: the Cecils had been an important force in St Martin's in the Elizabethan and early Jacobean period. But they were never the sole influence in the parish, and theirs was a control that was exercised with a velvet glove through an extensive and socially diverse network of local patronage, their local authority also deriving from their position as

\footnotetext{
${ }^{87}$ Merritt, Social World, pp. 124, 130-7; H.R. French, 'Social status, localism and the “middle sort of people” in England 1620-1750', Past \& Present clxvi (2000).

${ }^{88}$ BL, Harl. MS 1831 fo. 35v.
} 
high stewards of Westminster. ${ }^{89}$ Bedford by contrast seems to have sought more exclusive control and to have engaged directly and abrasively with the local community.

The creation of a new parish also raised in awkward form the question of who should be taken to speak for and embody the local community, not the least because the vestry and churchwardens emerged without any obvious consultation with the inhabitants. A new parish could not have 'ancients of the parish' of the sort whose authority was invoked in the mother parish of St Martin's. ${ }^{90}$ There was no corpus of custom and tradition to call upon, no gradually evolved hierarchy of prestige deriving from office-holding, service and local munificence. Petitions were normally respected as expressions of communal opinion, but the question of how far they were truly representative of opinion constantly recurred in the Covent Garden disputes. ${ }^{91}$ Time and again, we meet with complaints that different sides were claiming to speak for the

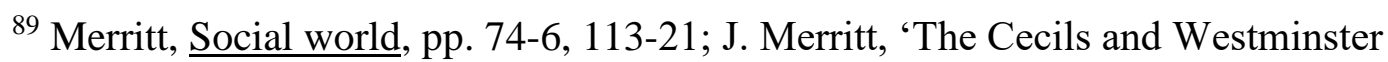
1558-1612: the development of an urban power base' in P. Croft (ed.), Patronage, culture and power (New Haven, 2002), pp. 231-48.

${ }^{90}$ On the use of the term 'ancients of the parish' see Merritt, Social world, p. 137; French, 'Social status', pp. 75-6, 98.

${ }^{91}$ On the rhetoric and practical ambiguities of petitioning in this period see D. Zaret, Origins of democratic culture: printing, petitions, and the public sphere in earlymodern England (Princeton (NJ), 2000); P. Lake, 'Puritans, popularity and petitions: local politics in national context, Cheshire, $1641^{\prime}$ in T. Cogswell, R. Cust and P. Lake (eds.), Politics, religion and popularity in early Stuart Britain (Cambridge, 2002), pp. 259-89; J. Walter, 'Confessional politics in pre-civil war Essex: prayer books, profanations, and petitions', Historical Journal xliv (2001), 677-701. 
'inhabitants' when in fact they only really articulated the views of an unrepresentative minority. Were those who agreed the new articles of the Covent Garden chapelry really representative of opinion in St Martin's? Were the signatories of the antiBedford petition truly representative of opinion in the precinct? Or were the signatories of the petition complaining of St Martin's intervention in February 1641 really speaking for the chapelry? Whose opinions did the 1660 petitioners really articulate? The fact that these questions were all disputed partly reflects the important rhetorical power that petitions could command, but also shows how open the issue of communal identity was in Covent Garden at this time. For all the disputes, however, the assumption that there was a single true voice of Covent Garden's inhabitants was never directly challenged.

The creation of St Paul Covent Garden also presents us with an intriguingly re-configured view of the religious politics of the period. There is a temptation to depict the 1630s as a time where Laudian ceremonial was the crucial issue in dispute, and where the court-supported forces of clerical authority and church re-edification were ranged against puritanism, lay encroachment in church affairs and popular petitioning by parishioners resentful of Laudian intrusions. In the particular case of Covent Garden, however, these associations and oppositions were configured differently. This was a new church building that was not the work of Laudians (clerical or lay), and at issue was not whether Bedford was a puritan, or what his attitude was to church ceremonies, or whether the style and the alignment of the church reflected puritan ideals. ${ }^{92}$ Laud's anxieties would seem to have been prompted

\footnotetext{
${ }^{92}$ In fact, the church interior would seem to have met with Laudian specifications: the act of consecration in 1638 declared that the new church had been built 'with an Alter or sacred table included with rayles': BL, Harl. MS 1831 fo. 31r.
} 
by Bedford's role as the donor and the peer's determination to control the church, as well as the immediate locality's previous flirtations with puritanism and links to the feoffees for impropriations. But Laud's involvement in events was rather ambiguous. He was ready in the end to bow to Bedford's longer-term control of the new parish, and was also apparently suspicious of the parishioners' motives in attacking the earl. Similarly, popular petitioning here took the form, not of puritan complaints about Laudian innovation or heavy-handed government intervention, but rather of condemnations of Bedford's apparent disregard of the principles of consecration, his attempt to control the church, and his failure to erect a proper statue of Charles I. But this petitioning was still 'popular', for all its loyalist posturing, and for Laud and Charles it would seem in the end that it was deemed preferable to support an overweening aristocratic patron - even one who was determined to take control of the local church - rather than the 'tradesmen' petitioning against him.

But did Laud and Charles partly get it wrong? Bedford in the end makes a much more obvious patron of puritans than do his critics. His local activist Anthony Wither was a strong supporter of the puritan lecturer Foxley. It was Wither who petitioned for Foxley's release from prison in 1640, and it may well have been Foxley and Wither who were the go-betweens when Bedford and the feoffees were mooting the sale of the advowson of Covent Garden. ${ }^{93}$ By contrast, none of the anti-Bedford petitioners seem to have had puritan credentials. Hulbert lacked obvious puritan contacts, and he was not a member of the puritan-favouring vestry of St Martin's of the 1620 s and early 1630s (the one local appointment that he had surprisingly missed). Privy councillors' fear of apparently popular petitioning against Bedford can appear all the more ironic. Bedford may have questioned the social standing and

\footnotetext{
${ }^{93}$ HLRO, Main Papers 1640 (undated).
} 
representativeness of Hulbert and his fellow-petitioners, but he and his son-in-law Lord Brooke would soon pose a much more direct threat to royal authority: in 1640 they were in treasonous contact with the Scots and were both signatories of the Petition of the Twelve Peers. ${ }^{94}$ By contrast, the anti-Bedford petitioners, who may have been seen as a dangerous 'popular' group making personal attacks on a member of the aristocracy, included a number of people who went on to sign the Westminster peace petition of 1642-3, whereas Bedford's supporters are notable in their absence among the nearly 3,000 signatories..$^{95}$

${ }^{94}$ Adamson, Noble revolt, pp. 45-6, 55-6, 59-60. Bedford's client Anthony Wither had also been examined before the Attorney General in August 1637 over his receipt of a copy of Prynne's 'Remonstrance against ship money': Lambeth Palace Library, MS 1030, fo. 133.

${ }^{95}$ HLRO, Main Papers 20 Dec. 1642. The final text of the petition is reproduced in Lords' Journals, V, 507. Signatories who had also signed the anti-Bedford petition include Stephen Chase, Joseph Lider, Gert Otton, Gifford Messes, William Ramsay, Henry Halfepenny, Peter Le Huc, John Hanger and Thomas Gunninge. The only apparent exception to this pattern is John Chicheley, who signed both the 'vestry' report on the anti-Bedford petition in 1638 and the February 1641 petition for the release of chapelry officials, as well as the peace petition. Ultimately, though, there are no clear patterns of civil war allegiance discernible among Covent Garden's factions. Most stayed in Westminster throughout the civil war and after, and many continued to hold local office. See my forthcoming monograph Westminster and the English Revolution. 
Covent Garden's most striking architectural features emphasized a uniformity and order that might appear to be the successful manifestation of the broader royal preoccupation with unity and hierarchy. But with the years of stalemate between the founder and the ecclesiastical authorities which left the church unconsecrated, the endless conflicting petitions of 'the inhabitants', the local memory of Bedford's supposed betrayal, and the ambiguous and oft-challenged parochial government, St Paul's parish manifested the messier reality of compromises and unresolved controversies that so often lay behind the rhetoric of the 1630s. 